\title{
Tensile Properties of a Hot Stretch Formed Ti-6Al-4V Alloy Component for Aerospace Appli- cations
}

Antonello Astarita, Umberto Prisco

Department of Chemical, Materials and Production Engineering, University of Napoli Federico II. Piazzale Tecchio 80, 80125 Napoli. Italy. E-mail: antonello.astarita@unina.it, umberto.prisco@unina.it

Comprehensively considering the analysis results of the microstructure, hardness and tensile properties, different zones of a component for aircraft applications manufactured through hot stretch forming were studied. The differential thermomechanical story of each studied zone of the forging was taken into account. The results reveal that the different zones strain hardened in function of the degree of the strain and strain rate experienced during the forming, with the zones most stressed at the higher strain rate showing the best tensile properties and a loss of ductility. This phenomenon is not coupled with a visible change into the microstructure morphology of the processed material.

Keywords: Hot stretch Forming, Titanium Alloys, Ti-6Al-4V, Tensile Properties, Strain Hardening

\section{References}

[1] XIAO, J., LI, D., LI, X., DING, P., ZHAO, K., HUANG, X., XU, M. (2015). Process Parameters Optimization of Ti-6Al-4V Alloy Sheet during Hot Stretch-Creep Forming. In: Transactions of Nonferrous Metals Society of China, Vol. 25, pp. $420-428$.

[2] ASTARITA, A., GIORLEO, L., SCHERILlO, F., SQUILlACE, A., CERETTI, E., CARRINO, L. (2014). Titanium Hot Stretch Forming: Experimental and Modeling Residual Stress Analysis. In: Key Engineering Materials, Vol. 611-612, pp. $149-161$.

[3] AStarita, A., ARMentani, E., Ceretti, E., Giorleo, L., MA Strilli, P., PARAdiso, V., SCHERILLO, F., SQUILLACE, A., VELOTTI, C. (2013). Hot Stretch Forming of a Titanium Alloy Component for Aeronautic: Mechanical and Modeling. In: Key Engineering Materials, Vol. 554-557, pp. 647 - 656.

[4] LIBERINI, M., SCHERILLO, F., ASTARITA, A., PRISCO, U., BRUNO, M., MONETTA, T., BELLUCCI, F., SQUILLACE, A., (2016). Microstructure of a Hot Forged Ti 5-5-5-3 Aeronautical Component. In: Metallography, Microstructure, and Analysis, Vol. 5, No. 3, pp. 207 - 216.

[5] ZHAO, J., ZHAI, R., QIAN, Z., MA, R. (2013). A Study on Springback of Plane Stretch-Bending in the Loading Method of Pretension and Moment. In: International JournalofMechanicalSciences, Vol. 75, pp. 45 - 54.

[6] DENG, T., LI, D., LI, X., DING, P., ZHAO, K. ( 2014 ). Hot Stretch Bending and Creep Forming of Titanium Alloy Profile. In: Procedia Engineering, Vol. 81, pp. 1792 - 1798.

[7] POLEN, L.A., HOUSTON, T.S., OWENS, J.E. (2014). Stretch Forming Apparatus with Supplemental Heating and Method. US, Patent N0.2 US 8,661,869 B2.

[8] GUPTA, R. K., MATHEW, C., RAMKUMAR, P., (2015). Strain Hardening in Aerospace Alloys. In: Frontiers in Aerospace Engineering, Vol. 4, No. 1, pp. 1 - 13.

[9] PRISCO, U. (2015). Size-Dependent Distributions of Particle Velocity and Temperature at Impact in the ColdGas Dynamic-Spray Process. In: Journal of Materials Processing Technology, Vol. 216, pp. 302 - 314.

[10] LUO, J., MIAOQUAN, L., WEIXIN, Y., HONG, L. (2010). The Variation of Strain Rate Sensitivity Exponent and Strain Hardening Exponent in Isothermal Compression of Ti-6Al-4V Alloy. In: Materials and Design, Vol. 31, No. 2, pp. $741-748$.

[11] PRISCO, U. (2014). Thermal Conductivity of Flat-Pressed Wood Plastic Composites at Different Temperatures and Filler Content. In: Science and Engineering of Composite Materials, Vol. 21, No. 2, pp. 197 - 204.

[12] SERRONI, G., SQUILlACE, A., PRISCO, U., BITONDO, C., PRISCO, A. (2011). Aircraft Panels Stiffened by Friction Stir Welded Extruded Parts: Mechanical Characterization. In: Metallurgia Italiana, Vol. 103, No. 1, pp. $35-39$.

[13] ZEMAN, P., BACH, P., TRMAL, G. (2017). Tool Life of PM-HSS Cutting Tools when Milling of Titanium Alloy. In: Manufacturing Technology, Vol. 17, No. 1, pp. $115-121$ 
[14] LATTNER, R., HOLEŠOVSKÝ, F., NOVÁK, M., VRABEL, M. (2016).Grinding of Titanium Alloy Ti6Al4V with Silicon Carbide Grinding Wheel. In: Manufacturing Technology, Vol. 16, No. 1, pp. 159 - 162.

[15] KUČEROVÁ, L., JIRKOVÁ, H., MAŠEK, B. (2016). Influence of Nb Micro-Alloying on TRIP Steels Treated by Continuous Cooling Process. In: Manufacturing Technology, Vol. 16, No. 1, pp. 145 - 149.

[16] SYMONOVA, A., DUCOBU, F., WEISS, V. (2016). The Mechanics of Machining Ultrafine-Grained Grade 2 Ti Processed Severe Plastic Deformation. In: Manufacturing Technology, Vol. 16, No. 3, pp. 627 - 633.

Copyright $($ 2017. Published by Manufacturing Technology. All rights reserved. 